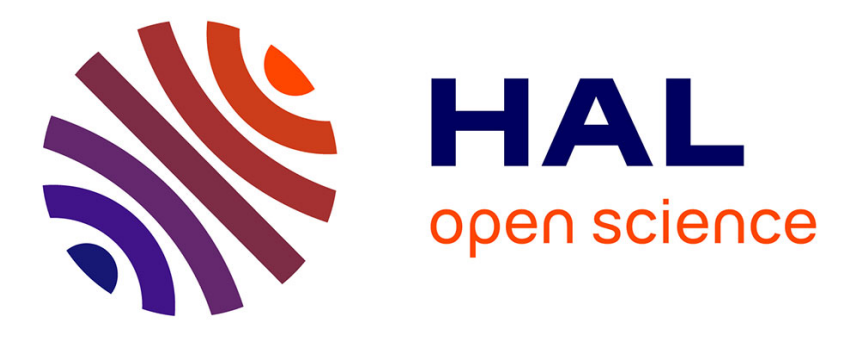

\title{
Foreign direct investment: lessons from panel data
}

Pierre Blanchard, Carl Gaigné, Claude Mathieu

\section{To cite this version:}

Pierre Blanchard, Carl Gaigné, Claude Mathieu. Foreign direct investment: lessons from panel data. The econometrics of panel data. Fundamentals and recent developments in theory and practice, 46, Springer-Verlag, 2008, Advanced Studies in Theoretical and Applied Econometrics, 978-3-540-75889-1. 10.1007/978-3-540-75892-1 . hal-01462333

\section{HAL Id: hal-01462333 https://hal.science/hal-01462333}

Submitted on 6 Jun 2020

HAL is a multi-disciplinary open access archive for the deposit and dissemination of scientific research documents, whether they are published or not. The documents may come from teaching and research institutions in France or abroad, or from public or private research centers.
L'archive ouverte pluridisciplinaire $\mathbf{H A L}$, est destinée au dépôt et à la diffusion de documents scientifiques de niveau recherche, publiés ou non, émanant des établissements d'enseignement et de recherche français ou étrangers, des laboratoires publics ou privés. 


\title{
Chapter 20 \\ Foreign Direct Investment: Lessons from Panel Data
}

\author{
Pierre Blanchard, Carl Gaigné and Claude Mathieu
}

\subsection{Introduction}

Since the 1980s, foreign direct investment (FDI) flows have grown substantially, especially throughout OECD countries (UNCTAD (2002)). The average share of FDI outflows in GDP went from around $2 \%$ in 1985 to almost $11 \%$ by the end of the 1990s. In 2000, OECD countries were the source of $90 \%$ FDI flows, and the recipient of $79 \%$. International corporations are now major actors in international trade since their contribution to global production climbed to $11 \%$ in 2001 . It is not surprising that, over the last two decades, FDI has spawned a significant amount of academic research and the literature continues to grow at an impressive rate. The empirical literature has expanded at a rapid pace in many different directions. Regardless of the question studied, the nature of the problem itself generally requires using panel data estimation methods because flows (or stocks) of FDI between pairs of countries (or between country-industry pairs) are analyzed for one or several time period. The purpose of this chapter is to provide a selective survey of the empirical literature using panel data.

As we will see in the next section, the theoretical literature has identified two dimensions acting upon the structure of FDI. The main components of firm/industry characteristics are transport costs, plant scale economies and factor intensities whereas market size, tariff levels and factor abundance are the main components of country features. As a result, using the econometrics of panel data is a natural way to evaluate the determinants to FDI. This issue is discussed in Sect. 20.3. In Sect. 20.4,

Pierre Blanchard

Erudite, Faculté de Sciences Economiques et de Gestion, Université Paris XII Val de Marne, 61 Av. du Général de Gaulle, 94010 Créteil Cédex, France, e-mail: blanchard@univ-paris12.fr

Carl Gaigné

INRA, UMR1302, SMART, F-35000 Rennes, France, e-mail: gaigne@ rennes.inra.fr

Claude Mathieu

Erudite, Faculté de Sciences Economiques et de Gestion, Université Paris XII Val de Marne, 61

Av. du Général de Gaulle, 94010 Créteil Cédex, France, e-mail: mathieu@univ-paris12.fr 
we present three types of empirical studies using the econometrics of panel data. The first type concerns the trade-off between producing at home or abroad. The second type studies more precisely the role of trade policies (anti-dumping, threat of protectionism, custom union) in the decision to establish an additional plant in a foreign country. The last type focuses on the impact of financial factors on the level of FDI. In the last section, we discuss recent econometric issues related to estimating FDI models using panel data.

Before presenting the micro-foundations of the decision to produce abroad, we have to define foreign direct investment. FDI refers to investments by multinational firms (MNF) in affiliates or subsidiaries. It consists of two broad categories: (i) direct net transfers from the parent company to the foreign affiliate, either through equity or debt; and (ii) reinvested earnings by a foreign affiliate. FDI is generally thought as a real capital flow between countries, the main interest in our analysis. Still, statistical information on FDI involves financial flows that do not necessarily correspond to an international allocation of productive capital. Indeed, FDI is comprised of several types of capital. First, it contains real investment in plants and equipment, either in the form of new plants and equipment or plant expansion. Second, a major part of FDI consists of the financial flows associated with mergers and acquisitions. This implies an ownership change in the absence of any real investment. OECD (2000) estimates suggest that mergers and acquisitions account for more than $60 \%$ of all FDI in developed countries. Others components of FDI are joint ventures and equity increases. The latter component typically comprises investment in financial capital. The distinction between the various types of FDI is important because the different components may have different explanations.

\subsection{A Simple Model of FDI}

In the 1980s, trade economists proposed refinements of the factor-proportions approach to explain the emergence of multinational corporations (e.g. Helpman (1984)). They determine the conditions under which firms have an incentive to become a "vertical" multinational, that is to separate headquarters from plant. A vertical multinational activity arises between countries that differ significantly in relative endowments. However, in order to explain the existence of foreign direct investments among similar countries, an alternative approach has been proposed by different authors (e.g. Markusen (1984)). The purpose is to determine the conditions under which firms produce the same product in multiple plants, serving local markets by local production. A firm will probably be a horizontal multinational when trade costs are relatively high and plant-level scale economies are low enough. This theoretical literature on FDI is generally characterized by general equilibrium models (see Markusen (1995)). However, in order to make the results accessible, we do not develop a general equilibrium model of plant location in this section. The objective of this section is to show basic mechanisms at work by developing a simple model of foreign investments, which is close to Markusen (2002). We will see 
how the main characteristics of technologies and countries interact to determine the choice of firms to engage in FDI and the type of FDI (horizontal or vertical). Technology features include plant-level and firm-level scale economies whereas country features include trade costs and global market size as well as differences in market size and marginal costs of production.

\subsubsection{Assumptions and Preliminary Results}

Consider one good produced by a single firm and sold in two markets/countries ( $h$ and $f$ ). Countries may differ in population size and/or in technology. The production of the good implies two types of sunk cost: a plant-specific fixed cost $(G)$ by production unit and a firm-specific cost $(F)$. Consumers are internationally immobile and both markets are segmented. The firm practices third degree price discrimination without threat of arbitrage by consumers. There are three alternatives modes of serving both markets. (i) By a national firm with a single plant located in country $h$ (type- $n$ ). The national firm serves country $f$ by exporting, which implies operational costs $t$ such as transportation costs as well as other nontariff trade barriers. We assume that $t$ is symmetric between countries. (ii) By a horizontal multinational with two plants located in both countries (type- $h$ ). The horizontal multinational serves country $f$ by establishing a subsidiary abroad, which implies further plant-specific fixed cost $G$. (iii) By a vertical multinational with the headquarter located in country $h$ and one plant in country $f$ that serves both markets (type-v).

The inverse demand function in each country is given by

$$
p_{i j}=a-\left(b / L_{i}\right) q_{i j}
$$

where $p_{i j}, q_{i j}$ are price and quantity of the good produced in country $i=h, f$ and sold in country $j=h, f$. In addition $L_{i}$ is the population in country $i=h, f$. We assume that $a, b>0$.

The expression of profits of a type- $n$ firm is expressed as follows:

$$
\pi^{n}=\left(a-\left(b / L_{h}\right) q_{h h}\right) q_{h h}+\left[\left(a-\left(b / L_{f}\right) q_{h f}\right)-t\right] q_{h f}-c_{h}\left(q_{h h}+q_{h f}\right)-G-F
$$

where $c_{h}$ is the marginal cost of production prevailing in country $h$, and $F$ a firmspecific fixed cost. By solving the first-order conditions, the profit-maximizing output in both markets is given by,

$$
q_{h h}^{*}=\frac{a-c_{h}}{2 b} L_{h} \quad \text { and } \quad q_{h f}^{*}=\frac{a-c_{h}-t}{2 b} L_{h}
$$

Consider now that the firm is a horizontal multinational. Its profit function is

$$
\pi^{h}=\left[\left(a-\left(b / L_{h}\right) q_{h h}\right)-c_{h}\right] q_{h h}-G+\left[\left(a-\left(b / L_{f}\right) b q_{f f}\right)-c_{f}\right] q_{f f}-G-F
$$


The supply on the foreign market corresponds to

$$
q_{f f}^{*}=\frac{a-c_{f}}{2 b} L_{f}
$$

Note that the supply on the domestic market is $q_{h h}^{*}$ from (20.3).

Finally, when the multinational adopts a type-v structure, its profit equation is expressed as follows:

$$
\pi^{v}=\left[\left(a-\left(b / L_{h}\right) q_{f h}\right)-c_{f}-t\right] q_{f h}+\left[\left(a-\left(b / L_{f}\right) q_{f f}\right)-c_{f}\right] q_{f f}-G-F
$$

Maximizing (20.6) gives the export sales from country $f$ to country $h$ :

$$
q_{f h}^{*}=\frac{a-c_{f}-t}{2 b} L_{h}
$$

whereas the sales in country $f\left(q_{f f}^{*}\right)$ are given by (20.5).

We can now summarize the total profits under the three alternative modes of serving country $h$ and $f$ by introducing (20.3), (20.5) and (20.7) in (20.2), (20.4) and (20.6), respectively,

$$
\begin{aligned}
\pi^{n} & =\left(\frac{a-c_{h}}{2 b}\right)^{2} L_{h}+\left(\frac{a-c_{h}-t}{2 b}\right)^{2} L_{f}-G-F \\
\pi^{h} & =\left(\frac{a-c_{h}}{2 b}\right)^{2} L_{h}+\left(\frac{a-c_{f}}{2 b}\right)^{2} L_{f}-2 G-F \\
\pi^{v} & =\left(\frac{a-c_{f}-t}{2 b}\right)^{2} L_{h}+\left(\frac{\alpha-c_{f}}{2 b}\right)^{2} L_{f}-G-F
\end{aligned}
$$

\subsubsection{Technology and Country Characteristics as Determinants of FDI}

The previous three profit equations enable us to determine the main factors that determine the choice for a firm about whether or not to engage in foreign investment and the type of FDI (horizontal or vertical). To simplify the analysis, we assume that $a>c_{h} \geq c_{f}$ and $L_{h} \geq L_{f}$ where $a$ is sufficiently large as well as $L_{f}$. We consider four configurations: (i) the characteristics of both countries are identical; (ii) the size of the home market is larger; (iii) the marginal cost of production is lower in the foreign country; (iv) combination of cases (ii) and (iii).

(i) First, we assume that countries are identical with respect to technology and factor endowments $\left(c_{h}=c_{f}=c\right.$ and $\left.L_{h}=L_{f}=L\right)$. So, we have $\pi^{n}=\pi^{v}$. Trivial calculations show that the firm decides to produce in both countries $\left(\pi^{h}>\pi^{n}\right)$ if and only if trade costs are high enough or equivalently when $t>t^{n h}$ where 


$$
t^{n h} \equiv(a-c)\left(1-\sqrt{1-\frac{4 b G}{L_{f}(a-c)^{2}}}\right)>0
$$

The threshold value $t^{n h}$ increases when $G$ declines and decreases when the population size of countries $(L)$ grows. In other words, the firm will be likely a horizontal multinational when trade costs are high relatively to plant scale economies and when the markets to serve are large enough.

(ii) Assuming now that countries are only different in population size with $c_{h}=c_{f}=c$ and $L_{h}>L_{f}$. Therefore, country $h$ has an advantage in market size. In this case, regardless of values of trade costs, profits when the firm adopts a type- $n$ structure is always superior to profits when it chooses a type- $v$ structure $\left(\pi^{n}>\pi^{v}\right)$. The critical value of trade costs above which the national firm becomes a horizontal multinational is identical to $t^{n h}$, except that $L_{f}$ is now lower than $L_{h}$. As a result, it appears that, when the market size is higher at home, convergence in population size between countries prompts the firm to establish a second plant abroad.

(iii) We now consider the case where countries are only different in production costs with $c_{h}>c_{f}$ and $L_{h}=L_{f}=L$. Stated differently, country $f$ has an advantage in production costs. In this configuration, we have $\pi^{n}<\pi^{v}$ regardless of trade costs. When production costs differ among countries, the firm has a strong incentive to become vertical multinational. In addition, the multinational produces in both countries if and only if $t>t^{v h}$ where

$$
t^{v h}=\left(a-c_{f}\right)\left(1-\sqrt{1-\frac{4 G}{b^{2} L\left(a-c_{h}\right)^{2}}}\right)
$$

It is readily confirmed that horizontal direct investments are favored when marginal costs converge.

(iv) Finally, with $c_{h}>c_{f}$ and $L_{h}>L_{f}$, we consider the case where the advantage in market size benefits country $h$ while the advantage in production costs benefits country $f$. This configuration is more complex because we must rank three profit equations: $\pi^{v}, \pi^{n}$ and $\pi^{h}$. Figure 20.1 shows graphically the profits of each regime against trade costs. It is straightforward to check that $\pi^{v}(t=0)>\pi^{n}(t=0)$ and that profits in both structures (type- $v$ and $-n$ ) decline when trade costs increase. In addition, we have $\pi^{v}(t=0)>\pi^{h}$. As a result, the multinational is more likely to have a vertical structure when trade costs are very low. Further, as profits do not vary with respect to trade costs when the firm is characterized by a type- $h$ structure (see the dashed lines in Fig. 20.1), a horizontal FDI is more likely to take place when trade costs are high enough. Finally, the firm becomes national when trade costs take intermediate values. Note that the relative position of the profit curves depends on the size of plant scale economies $(G)$. More precisely, a fall in $G$ increases the profits more when the multinational is located in both countries than when the firm produces in a single country. 


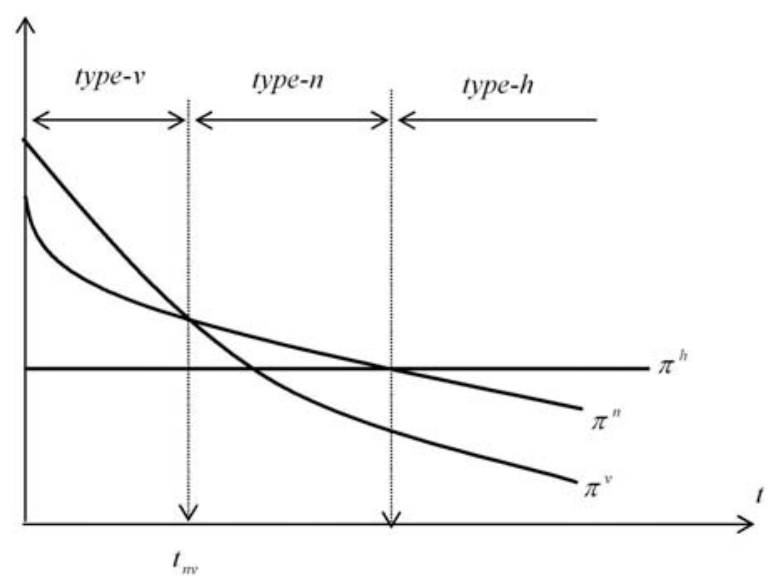

Fig. 20.1 Profit functions according to the firm type

Observe also that we have $\pi^{v}(t)>\pi^{n}(t)$ if and only if $t<t_{n v}$ where

$$
t_{n v} \equiv\left(c_{h}-c_{f}\right) \frac{L_{h}+L_{f}}{L_{h}-L_{f}}
$$

Then, the firm is likely to prefer to serve both countries from the foreign country when trade costs are low enough. In addition, when the size of markets diverges noticeably ( $L_{h}$ grows or $L_{f}$ declines), the type- $v$ firm is more likely to occur $\left(t_{n v}\right.$ increases). Consequently, the advantage in production costs dominates the advantage in market size when trade costs are sufficiently low, while the advantage in market size dominates the advantage in production costs when trade costs are high enough.

To summarize our analysis, we first recall the main conditions under which a firm engages in horizontal FDI: countries are similar in market size and in marginal production costs, the "world" demand is sufficiently high, the plant-specific fixed cost is low relative to the firm-specific fixed cost and trade costs are high enough. In addition, the firm is more likely to be a vertical multinational when trade costs are low enough and when the difference in production costs is sufficiently high. Finally, notice that FDI and trade are substitutes when multinationals are horizontal and complementary when multinationals are vertical.

\subsection{Econometric Implementation and Data}

The basic model of the previous section has allowed us to identify the factors acting upon the emergence of FDI at two levels: at firm/industry level (technology, plant scale economies, factor intensities and transport costs) and at country level (market size, tariff levels and factor endowments). As a result, panel data models have been 
extensively used for analyzing the factors determining the international allocation of foreign investments.

\subsubsection{A General Econometric Model}

Ideally, in order to control for observed and unobserved heterogeneity between host and domestic countries and for time effects, we need to estimate triple indexed models (see Matyas (2001), Egger and Pfaffermayr (2003)). A basic specification ${ }^{1}$ is, for instance,

$$
\mathrm{FDI}_{i j t}=\mathbf{x}_{i j t} \beta+\alpha_{i}+\lambda_{j}+\gamma_{t}+\delta_{i j}+u_{i j t}
$$

where $\mathrm{FDI}_{i j t}$ is the amount of outward FDI of country $i$ (home) held in the country $j$ (host) at year $t$ and $\mathbf{x}_{i j t}$ is a vector of regressors. ${ }^{2}$ As suggested by the theoretical model, the variables included in the regressors list may be: a measure of bilateral country size (e.g. the sum of bilateral GDP); an index of size similarity; one or more measure of differences in relative endowments (e.g. capital stock and/or skilled labor ratios between the home and host countries); a variable measuring trade costs (tariffs, distance, for example). Nevertheless, several variables are added in order to control for investment, political, financial risks, non tariff barriers, openness policy... Because the specification takes into account the effect of "gravity" factors (e.g. market size, distance), this model is usually called the gravity model and is commonly used not only for FDI analysis but also for modelling trade between countries. The parameters $\alpha_{i}$ and $\lambda_{j}$ are introduced in order to control for heterogeneity across (host and domestic) countries (due for instance to legal or cultural characteristics) whereas $\gamma_{t}$ captures any time-specific effect common to all pairs of countries such as business cycle effects, or changes in the degree of openness across all economies. The term $\delta_{i j}$ accounts for all time-invariant effects between two given countries such as common language and common borders. ${ }^{3}$ These effects are modelled either as fixed (fixed effects model) or as random (random effects model) or, in very few studies, with a random coefficients specification (e.g. Feinberg and Keane (2001) and Balestra and Negassi (1992)). The Hausman test is frequently used in order to choose between the fixed effects and the random effects specification.

A second reason for using panel data for estimating FDI models relies often on the necessity to take into account the correlation between contemporaneous FDI flows and those of the previous year due to adjustment and sunk costs. By

\footnotetext{
${ }^{1}$ A more general specification is given by Baltagi, Egger and Pfaffermayr (2003). See Sect. 20.4.

${ }^{2}$ Several variants of this specification are frequently used in applied works, e.g.: (i) one can explain bilateral FDI from country $i$ to country $j$ for a given year $\left(\mathrm{FDI}_{i j}\right)$. (ii) It is also possible to focus on FDI from a given home country to several host countries at time $t$ (FDI ${ }_{j t}$ ) or in sector $s$ at time $t$ for each host country $j\left(\mathrm{FDI}_{j s t}\right)$; (iii) one can also model FDI from a parent firm $i$ to affiliates $j$ at time $t\left(\mathrm{FDI}_{i j t}\right)$.

${ }^{3}$ Note also that the country-pair effects may differ according to the direction of FDI (i.e. $\delta_{i j} \neq \delta_{j i}$ ) which can be tested for.
} 
including $\mathrm{FDI}_{i j t-1}$ in the model, we have a dynamic specification of FDI. Although this allows us to distinguish between short-run and long-run effects, it creates a correlation between the lagged dependant variable and the error term. However in this case, the usual estimators (OLS, within, GLS) are biased and inconsistent (for short $T$ ). With panel data, this problem may be solved by transforming the model in first differences. Moreover, using the time dimension, we can quite easily find instruments for endogenous regressors, $\mathrm{FDI}_{i j t-1}$ of course, but also for other explanatory variables which may be endogenous in such a context, e.g. GDP, exchange rate.

Therefore, it is not surprising that a vast and recent econometric literature using panel data has emerged on these topics with a great variability in the estimation methods used.

\subsubsection{FDI and Data Issues}

Testing model (20.14) requires data that vary in different dimensions (firm/ industry, country and time). There are two main types of data on foreign direct investment: (i) the balance of payments provides information on inward and outward flows of FDI and the stocks derived from accumulated FDI flows. Such data are available at country level and vary over time; (ii) the second type of data is about operations of individual multinational firm at home and abroad. We discuss the advantages and disadvantages of these two types of data sets.

Type (i). Different international institutions publish international data on FDI based on the balance of payments, such as the International Monetary Fund (IMF), the United Nations (via the UNCTAD World Investment Report) and the Organization for Economic Cooperation and Development (OECD). These data sets cover many countries but many of them deviate significantly from the international guidelines for the compilation of balance of payments and international investment position statistics in the IMF's Balance of Payment Manual (5th edition) and in the OECD's Benchmark Definition of Foreign Direct Investment (3rd edition). We choose to describe more precisely the data provided by the OECD (see Lipsey (2001), for a description of data from IMF and United Nations) for two main reasons: first, FDI between OECD countries represent more than $60 \%$ of the overall FDI; second, these countries are more in accordance with the recommendations of Survey of Implementation of International Methodological Standards for Direct Investment (SIMSDI) which is a comprehensive study of data sources, collection methods, and dissemination and methodological practices for FDI statistics. The Directorate for Financial, Fiscal and Enterprise Affairs of OECD yields statistics on FDI transactions and positions, published under the title International Direct Investment Statistics Yearbook. The flows and stocks of FDI are compiled by using the balance of payments and the international investment positions, respectively. Both data sets are available for inward and outward FDI by partner country and by 
industry (according to ISIC Rev. 3 classifications) in the standard format defined by the international guidelines. A few OECD countries do not provide complete information and/or deviate from the agreed international standards established by the IMF. Moreover, the database covers 28 OECD countries over the 1980-2000 period. As a result, the cross-sectional comparability of the data is improving and balanced panels can be easily implemented (see IMF and OECD (2001) and Nicoletti, Golub, Hajkova, Mirza and Yoo (2003) for further details).

Type (ii). Although it is becoming more widely recognized that data need to account for heterogeneity between MNF, this type of information is still relatively scarce. Some countries collect information about inward FDI (France, Germany, Italy, among other) or outward FDI (Japan, see Falzoni (2000) for a description). With few exceptions, only the US and Sweden produce data for both outward and inward FDI. ${ }^{4}$ Moreover, information about the characteristics relative to the parent companies and their affiliates are less frequent. ${ }^{5}$ In fact, the US Bureau of Economic Analysis (BEA) provides the more extensive database about the operations of the affiliates and their parent companies. Indeed, available data give specific information about gross product, employment, wages and R\&D expenditures for each domestic or foreign unit belonging to a MNF. In the same vein, the Research Institute of Industrial Economics (IUI) in Sweden compiles a dataset which is based on a questionnaire sent to all Swedish MNF, containing information on parent companies as well as on the operations of each individual subsidiary (see Braunerhjelm, Ekholm, Grundberg and Karpaty (1996) for a detailed description of this database). However, this survey is only implemented approximately every four years since the 1960s. This means it is difficult to build a panel with a time dimension. Even though the BEA only conducts benchmark surveys every 5 years, its annual surveys can be used to build a more detailed panel dataset. A more important limit is that this dataset covers only US bilateral activity. Note that this limit is applied to all MNF databases developed by the different national official statistical departments (see for example the database on intra-firm international trade of the Department for Industrial Studies and Statistics (SESSI) of the French Ministry for Economic Affairs, Finance and Industry) and also to data gathered by private agencies (see Head and Ries (2001) for the database of Toyo Keizai on Japanese MNF). In addition, studies testing the trade-off between US export and FDI use the ratio of US exports to the sales of US multinational affiliates as the dependent variable. Indeed, the BEA's database does not contain firms which are only exporters. Consequently, the multinational firm sales must be aggregated at the level of industries in order to make comparable FDI and export data.

\footnotetext{
${ }^{4}$ See Stephan and Pfaffmann (1998) and Lipsey (2001) for a description and a discussion of different national sources of FDI as in Sweden, Germany, Japan and Canada.

${ }^{5}$ Note that these characteristics are not necessarily comparable when they exist (see for example the survey about the foreign affiliates of the French Ministry of Finance in 2000).
} 


\subsection{Empirical Estimations: Selected Applications}

\subsubsection{Testing the Trade-Off Between FDI and Exports}

\subsubsection{FDI Versus Exports}

A branch of the empirical literature on multinational production-location decisions has used the BEA database in order to study the determinants of FDI at the country/industry level. Within this literature, Brainard (1997) was the first to use direct industry- and country-specific measures of several determinants of FDI. Her objective is to test the determinants of the horizontal integration of multinationals (see Sect. 20.2). However, the author also controls for the possibility that multinational activity is motivated by gaining access to factor supplies (vertical integration). This work has been extended in two ways. First, Helpman, Melitz and Yeaple (2004) focus on the horizontal dimension of FDI location decision by taking into account the heterogeneity within sectors. In parallel, Yeaple (2003) controls more explicitly for the vertical dimension of FDI decisions by including the interaction between factor intensities and factor abundance. Combining the approaches of Brainard, Helpman et al. and Yeaple, the general empirical model is given by:

$$
E X S H_{j s}=\beta_{0}+\sum_{c} \beta_{c} \mathbf{c f t}_{j s}+\sum_{l} \beta_{l} \mathbf{s c a l e}_{s}+\beta_{u} U C_{j s}+v_{s}+\lambda_{j}+\varepsilon_{j s}
$$

where $\mathrm{EXSH}_{j s}$ is, in the three papers, the ratio of total US sales of good $s$ in country $j$ to the sum of local affiliate sales and exports from US to that host country. ${ }^{6}$ Note that Brainard and Yeaple consider also the share of US imports as a dependent variable. In this subsection, we only focus on outward foreign investment.

$\mathbf{c f t}_{j s}$ is a vector of trade costs, such as transport and insurance costs (FREIGHT ${ }_{j s}$ ) and tariff barriers $\left(\mathrm{TARIFF}_{j s}\right)$. In Brainard and Yeaple, FREIGHT $_{j s}$ is measured by the freight and insurance charges reported by importers to the US Bureau of Census to calculate freight factors such as the ratio of charges to import values. ${ }^{7}$ The data on TARIFF $_{j s}$ comes from a 1988/1989 database by the General Agreement on Tariffs and Trade on ad valorem tariffs at the 3-digit SIC level of industry. In Helpman et al., FREIGHT $j s$ is computed as the ratio of CIF imports into the US to FOB imports from the data presented by Feenstra (1997) whereas TARIFF $_{j s}$ is calculated at the BEA industry/country level.

scale $_{s}$ stands for scale economies in each industry. Two types of scale economies must be distinguished: at the corporate level $\left(\mathrm{CSCALE}_{s}\right)$ and at the plant level (PSCALE $)$. They correspond to $G$ and $F$ in our theoretical model, respectively. In Brainard, $\mathrm{CSCALE}_{S}$ is measured as the number of nonproductive workers in the

${ }^{6}$ Relatively to model (20.14), we deleted the subscript $i$ since we have one home country (the USA) and introduced a further dimension (the sector) indexed by the subscript $s$. Hence, $v_{s}$ is a sector-specific component, capturing the sectoral characteristics of firms in each country that are unobservable or omitted from equation, but do not vary over country.

${ }^{7}$ No comparable data are available from exporters. The authors assume that transport costs are symmetric, which introduces measurement error in the outward estimates. 
average US-based firm and, in Yeaple, as the average number of nonproduction employees at the firm level. In Brainard, $\mathrm{PSCALE}_{s}$ is defined as the number of production employees in the median US plant ranked by value added, whereas Yeaple uses the average number of production workers in the US plants. Helpman et al. calculate the average number of non-production workers at the six-digit level. They then compute this measure for every three-digit level as the average of the within three-digit sectors, weighted by the six-digit level sales in this sector.

The variable $U C_{j s}$ stands for unit costs of production, introduced in order to control for factor-proportions differences. In Yeaple, this cost is a vector of variables that reflect a potential host country's unit cost of production by sector. Brainard considers variations only in country characteristics since the proxy used is the differential in per-worker income whereas Helpman et al. use only cross-industry variations in technology such as capital and $R \& D$ intensities.

As expected, the studies by Brainard and Helpman et al. suggest that the share of affiliate sales is increasing in trade barriers, transport costs and corporate sale economies and decreasing in production scale economies. The empirical analysis of Brainard suggests also that the comparative advantage motive for FDI is far less important. These findings support the horizontal model of FDI. However, by considering the interaction between factor abundance and factor intensities at highly disaggregated level, Yeaple shows that the comparative advantage in production cost is also a key determinant of FDI.

\subsubsection{Horizontal Versus Vertical FDI}

The previous empirical works suggest FDI decision may be motivated by both horizontal and vertical considerations. Recent theoretical works, which are called knowledge-capital models (henceforth KC model), show that vertical and horizontal firms can emerge simultaneously (cf. Markusen, Venables, Eby-Konan and Zhang (1996), Markusen (1997)). The main feature of the KC models is that exploitation of factor-price differences interacts with multi-plant scale economies to explain the decision and the nature of foreign investments. The results of these models, arising from simulations, relate the decision to produce abroad to country characteristics. Examples of empirical papers in this field are Carr, Markusen and Maskus (2001) and Blonigen, Davies and Head (2003) as well as Markusen and Maskus (2002a,b). Again, the data used in these empirical studies comes from the US BEA, although data are aggregated across industries to the country-level to form a panel of cross-country observations over the period 1986-1994.

The KC model is a more elaborate version of the model developed in Sect. 20.2. The central idea is that the services of knowledge and knowledge-generating activities can be spatially separated from production and supplied to production facilities. As knowledge-based services are more skill intensive than production, the multinational corporations have an incentive to locate the first (resp., second) activity in country where skilled (resp., unskilled) labor is relatively cheap. Consequently, the multinational firm can be vertically integrated. In addition, the output of 
knowledge-base activities can be used simultaneously by multiple producers. Then, the existence of firm-level scale economies implies that the same products or services are produced in different countries. In this case, multinational firms can be horizontally integrated.

As in the theoretical model, three types of firms can emerge: (i) horizontal multinationals where plants are located in different countries and headquarters set up in the home country (type-h); (ii) vertical multinationals where production takes place in a single plant located in a foreign country while the headquarters are maintained in the home country (type-v); and (iii) national firms with a single plant where the production and knowledge-based services are located only in the home country (type- $n$ ). Given the new assumptions, the last regime is dominant in the country with the large market size and skilled worker endowment and when foreign investment barriers are high. Type- $h$ firms are likely to be dominant if transport costs are high enough and if the nations are similar in relative factor endowments as well as in size. In other words, if countries are dissimilar either in size or in factor endowments, one nation will be favored. For example, if nations have the same factor endowments but differ in size, firms located in the larger country benefit from lower production cost. Thus, vertical multinationals may emerge when the home country is skilled-laborabundant and small, unless trade costs from the host country (where production takes place) back to the parent country (where the headquarter is located) are too excessive.

Given mechanisms discussed above, Carr, Markusen and Maskus (2001) estimate the following equation:

$$
\begin{aligned}
\mathrm{FDI}_{i j t}= & \beta_{0}+\beta_{1} \mathrm{GDPsum}_{i j t}+\beta_{2}\left(\mathrm{GDP}_{d i} f_{i j t}\right)^{2}+\beta_{3} \mathrm{SKILL}_{i j} f_{i j t} \\
& +\beta_{4}\left[\mathrm{GDP} d i f_{i j t} \times \mathrm{SKILL} d i f_{i j t}\right]+\mathbf{m c}_{i j t} \gamma+\lambda_{j}+u_{i j t}
\end{aligned}
$$

The dependent variable $\left(\mathrm{FDI}_{i j t}\right)$ is the real volume of production (sales) by manufacturing affiliates in each host country $j$ that are majority owned by parents in domestic country $i$. The variable GDPsum G $_{i j t}$ is the bilateral sum of real GDP levels at home and abroad (the joint market size) whereas (GDPdif $\left.f_{i j t}\right)^{2}$ is the squared difference in real GDP between home and foreign countries. Then, SKILLdif $f_{i j t}$ stands for the difference in skilled-labor abundance in both countries. Note that the variable GDPdif $f_{i j t} \times$ SKILLdif $f_{i j t}$ captures the fact that affiliates sales are higher when the home country has a small size and is skilled-labour-abundant. Finally, $\mathbf{m c}_{i j t}$ is a vector of multinationalization cost variables such as the perceived costs of investing in, and exporting to, the host country as well as the perceived trade costs in exporting to the parent country.

A fixed effect $\left(\lambda_{j}\right)$ is introduced for each foreign country. The results with country-pair dummies are not reproduced in the paper. As expected, outward investment increases with the joint market size, the convergence in GDP between the parent country and any host country and the abundance in skilled workers of the parent nation. Moreover, when the country fixed effects are introduced, the difference in skill endowments has a smaller role but remains significant while the other variables keep the same impact. 
These results seem to offer direct support for the $\mathrm{KC}$ model and to reject the horizontal model. Indeed, the last model predicts that absolute skill difference is negatively related to affiliate sales (Markusen and Venables (2000)). In contrast, in $\mathrm{KC}$ model, the production of foreign affiliates grows when the difference in skilledlabour abundance declines. However, Carr, Markusen and Maskus (2001) estimate a pooled coefficient on a difference term that takes both positive and negative values. This introduces a substractive linear constraint which can lead to a sign reversal in the pooled or restricted coefficient. Indeed, when the difference is negative (resp., positive), the rise in differences implies a convergence (resp., divergence) in skilllabour endowments. From the same database, Blonigen, Davies and Head (2003) exactly replicate the analysis of Carr et al. except that they consider the absolute values of skill difference. In this way, these variables are always decreasing in skill similarity. With this correct specification, Blonigen et al. obtain coefficient signs that support the horizontal model. This result suggests that the preponderance of multinational activity in developed countries is horizontal in nature.

\subsubsection{Exports and FDI: Substitutes or Complements}

Another way to determine the preponderance of horizontal FDI is to test whether FDI and exports are substitutes or complements. Our analysis in Sect. 20.2 suggests that substitution is the expected relationship under horizontal investments. This result arises from the fact that this model focuses on trade in final goods. When intermediate goods are introduced, foreign investment and export may simultaneously increase or decrease. Indeed, the rise in the production of affiliates induces an increase in imported inputs from the home country which corresponds to intrafirm trade when they come from parent companies (see for example Feinberg and Keane (2006) Hanson, Mataloni and Slaughter (2005)). Then, sales abroad of final goods and exports of intermediate goods can be complements. Several studies have examined the empirical relationship between production abroad and exports.

From a panel of Japanese firms over time, Head and Ries (2001) show that overseas investment and exports are complements. This result is obtained for the entire sample and by controlling for fixed firm effects. However, when the sample concerns the large assemblers that are not vertically integrated, the production of plants located abroad and the exports are substitutes. By using data published by the BEA which varies by country and over time (between 1977 and 1994), Clausing (2000) finds evidence that US multinationals activity and US exports are complements. Indeed, by using a gravity equation specification of trade, the author shows that a rise in affiliate local sales net of the value of imports from the US parent company increases the US exports. This result is robust when country-specific effects are controlled for.

It is clear that the relationship between foreign investments and exports depends on the level of aggregation of data. The studies using firm-level data underestimate the complementary effect since firms may purchase a number of inputs from independent suppliers that are set up in their domestic country. At the opposite, when 
data are not disaggregated, the complementary effect is overestimated. Swenson (2004) examines how the change in US imports of product $k$ from country $i$ is related to changes in FDI stocks measured at three aggregation levels: product $k$ (3-digit), 2-digit industry which produces $k$ and overall manufacturing. By controlling for endogeneity, the empirical analysis reveals that US imports and foreign investment in US are substitutes at the product-level while, at the overall manufacturing level, they are complements. Note that any nation or industry fixed effects drop out from the estimating equation.

Finally, Egger (2001) proposes a dynamic treatment of the bilateral economic relationship, which would allow a useful distinction between short-run and longrun relationships. The analysis is based on a dynamic bivariate panel framework. The data cover the period 1986-1996 for bilateral relationships between the $15 \mathrm{EU}$ members. The empirical model is given by:

$$
\begin{aligned}
d E X_{i j t} & =\alpha_{0}+\alpha_{1} d E X_{i j t-1}+\alpha_{2} d \mathrm{FDI}_{i j t-1}+\alpha_{3} Z_{i j t}+\rho_{t}+\varepsilon_{i j t} \\
d \mathrm{FDI}_{i j t} & =\beta_{0}+\beta_{1} d E X_{i j t-1}+\beta_{2} d \mathrm{FDI}_{i j t-1}+\beta_{3} Z_{i j t}+\gamma_{t}+u_{i j t}
\end{aligned}
$$

where $d E X_{i j t}$ and $d \mathrm{FDI}_{i j t}$ are first differences of exports and stocks of outward FDI from country $i$ to country $j$ at period $t$, respectively. The use of first differences as well as the Hansen (1982) two-step generalized methods of moments controls for the correlation between lagged endogenous regressors and the error term. Note that exports is included in the FDI equation as a lagged variable. The explanation offered by the author is as follows: before setting up a plant in a country to serve this market, firms look at their export performance. Then, $Z_{i j t}$ is a vector of variables similar to (20.15) and (20.16). Finally, $\rho_{t}$ and $\gamma_{t}$ are time-specific fixed effects. These effects take into account business cycles affecting Europe as a whole. The estimated coefficients of the lagged endogenous variables are significant suggesting that adjustment costs play is a major role in FDI and exports. The estimation results indicate also that outward FDI does not influence exports in the short-run, and viceversa. Consequently, it is difficult to reach a clear conclusion on the complementary or substitutive nature of FDI and exports.

\subsubsection{Exports and FDI: The Role of Distance}

Among the key determinants of the decision to produce abroad, some variables such as distance and sunk costs do not vary over the time. However, using first differences or within transformation does not permit to measure the impact of all time invariant factors. ${ }^{8}$ In addition, these explanatory variables are likely to be correlated with the time effect. As a result, the Hausman-Taylor model should allow for testing the role of the distance in FDI and using time effects. The difficulty arises from the choice of variables which are considered as doubly exogenous (not correlated with the unobserved effects) and as singly exogenous (correlated with

${ }^{8}$ Note that Carr, Markusen and Maskus (2001) do not take into account this problem when they estimate the model (20.16). 
the unobserved effects). Although this econometric issue is very important, empirical papers presented in Sect. 20.4.1. do not take account of this bias. There are few papers using the Hausman-Taylor model to study the determinants of FDI. Egger and Pfaffermayr (2004a) is a notable exception. ${ }^{9}$ Their data concern FDI from the US and Germany to other countries between 1989 and 1999. By controlling for (fixed) time effects and (random) industry-country pair effects, the authors find that distance has a significant and positive impact on outward FDI and that exports and outward FDI are complementary in the US and (weakly) substitutes in Germany. Moreover, an over-identification test suggests that distance and relative factor endowments are singly exogenous.

\subsubsection{Testing the Role of Trade Policy in FDI}

Almost all empirical contributions reviewed in the previous subsection consider that tariff-jumping is an important motive for FDI. The role of tariff barriers in the decision to produce abroad has also received specific attention from several empirical analysis. These studies are important since they test the ability of policy makers to influence international trade and FDI. The recent interest in the impact of trade policy on the decision to produce abroad arises also from important reductions in tariffs, quota and voluntary export restraints (VERs) and from an increasing number of countries with anti-dumping laws, because of numerous multilateral trade agreements (see Baccheta and Bora (2001) and Blonigen and Prusa (2003)). Consequently, it is not surprising that the tariff-jumping FDI analysis has concerned three main aspects: (i) anti-dumping (AD) policies; (ii) the threat of a protectionist policy (the so-called quid pro quo FDI hypothesis); and (iii) the transition periods of trade liberalization. Again, the use of panel data econometrics is crucial in these three domains. Indeed, testing the role of (i), (ii) and (iii) requires data that vary over time and information at product/firm level.

\subsubsection{Effects of Anti-Dumping Laws}

As stated by Blonigen and Prusa (2003), Since 1980, GATT/WTO members have filed more complaints under the AD statute than under all other trade laws combined.... So, among other related questions, a growing number of empirical works using panel data study the effects of antidumping actions on FDI (these are mostly oriented toward Japanese firms).

By using a panel of 7 countries (6 EU members plus the US) over the period 1980-1991, Barell and Pain (1999) estimate a model which relates Japanese direct investment flows in country $j$ at time $t$ to a variable ${ }^{10}$ denoting the "discounted stock" of anti-dumping cases $\left(\mathrm{SAD}_{j t}\right)$ in the EU or in the US, where

\footnotetext{
${ }^{9}$ More precisely, a seemingly unrelated regression Hausman-Taylor model is considered because they specify a system of two equations, exports and outward FDI, as in Egger (2001).

${ }^{10}$ In addition to several other regressors, such as market size and relative labour cost.
} 


$$
\mathrm{SAD}_{j t} \equiv \mathrm{AD}_{j t}+\sum_{i}\left(\mathrm{AD}_{j t-i}\right) / i .
$$

In this way, past anti-dumping actions may have a persistent, but progressively weaker, effect on Japanese FDI. The model is estimated by using the within estimator. The main result is that the level of AD has a positive effect on FDI. However, the authors use a very aggregated and quite short panel data $(N=7$ and $T=12)$, even if they test carefully for the presence of heteroscedasticity and serial correlation of errors (see their Appendix A).

A more convincing analysis is provided by Blonigen (2002). ${ }^{11} \mathrm{He}$ first observes that: In August 1993, Eastman Kodak Company filed a US antidumping petition against US imports of photographic paper originating from plants owned by Fuji Photo Film in Japan and the Netherlands.... While this led to an ensuing suspension agreement that led to substantially lower imports for a brief period, Fuji soon located a photographic paper manufacturing plant to the United States.... AD duties may result from a complex mechanism which requires the use of very disaggregated data. They are observed by all firms, they may change over time when the foreign firm modifies its dumping behavior (it may obtain refunds of AD duties in some cases) or if the US Department of Commerce changes the way it fixes $\mathrm{AD}$ duties. For this reason, Blonigen uses a panel data including firm and product combinations involved in US anti-dumping investigations from 1980 through 1990. By using a probit model, the author evaluates the probability for a Japanese firm, subject to anti-dumping duties, of locating its production for a given product in the US. From a technical point of view, the model used is a pooled probit which includes industry dummies in order to control for unobserved industry characteristics. The main result is that AD duties have a significant but small effect on FDI probability. Moreover, this effect is stronger when the firm has previous multinational production experience.

One interesting variant of Blonigen's approach may be found in Girma, Greenaway and Wakelin (2002). The authors introduce a time dimension in the panel and apply a different estimation strategy. Their basic model explains the presence (measured in terms of employment or fixed assets) of Japanese firms in the UK by a set of explanatory variables including the cumulated number of anti-dumping cases against Japanese firms measured as in (20.18). In this way, past anti-dumping actions may have a persistent, but progressively weaker, effect on Japanese FDI. The panel consists of 223 sectors observed over 1988-1996. The variables are constructed by aggregation of firms data. This permits a better evaluation of the tariffs and cumulative anti-dumping variables, as well as accounting for their time variabilities. However, for 146 industries, the dependent variable is equal to zero. So, the authors use Heckman's two-step estimation method. In the first stage, they estimate the probability of having Japanese FDI in the sector by using a probit model. In the second stage, they restrain their sample to the sectors with strictly

\footnotetext{
11 Belderbos and Sleuwaegen (1998) follow broadly the same approach with data on Japanese FDI in the EU. They use a panel consisting of 131 firms and 345 (electronic) products, and so observed at a very disaggregated level. The authors confirm that VERs, antidumping actions and tariffs favor Japanese FDI and have a negative effect on firm-level exports to Europe.
} 
positive FDI and explain the level of FDI in these sectors by unit labor costs and the cumulative number of anti-dumping cases. Additionally, in order to control for a selectivity bias, the inverse Mills ratios estimated at the first stage are introduced in the second stage. The model also includes time dummy variables which capture some UK business cycle effects. The main result is that Japanese FDI in the UK depends significantly on anti-dumping actions, and, to a more limited extent, on VERs and tariff barriers.

\subsubsection{Effects of the Threat of Protectionism}

In the literature on the quid pro quo FDI hypothesis (see Bhagwati, Dinopoulos and Wong (1992) and Grossman and Helpman (1996)) FDI may be caused by the threat of protectionism, and not only by actual protectionism as in the tariff-jumping analysis. Foreign investment may be used by international corporations as an instrument to defuse a possible protectionist action. In this case, when a firm establishes an overseas local production unit and creates jobs, the host country has less incentives to adopt protectionist measures.

Testing the quid pro quo hypothesis is difficult because the threat of protection is not observed and must be distinguished from actual protection. ${ }^{12}$ Blonigen and Feenstra (1997) have proposed a solution using a less aggregated panel dataset of Japanese FDI in the US across 4-digit manufacturing industries from 1981 to 1988. First, they define the threat of protection in industry $i$ and year $t-1$ as a latent variable $\left(Z^{*}\right)$ defined by

$$
Z_{i t-1}^{*}=\mathbf{w}_{i t-1} \gamma+\eta_{i t-1}
$$

i.e. it relies on a set of variables $\mathbf{w}$ (including real Japanese import growth, US real GNP growth). Now, consider that we observe at time $t-1$ if an US anti-dumping action is being engaged $\left(Z_{i t-1}=1\right)$ or not $\left(Z_{i t-1}=0\right)$ by the administration against Japanese firms in a given industry. Suppose also that,

$$
\left\{\begin{array}{l}
Z_{i t-1}=1 \text { when } Z_{i t}^{*}>0 \\
Z_{i t-1}=0 \text { when } Z_{i t}^{*}<0
\end{array}\right.
$$

Hence, a US anti-dumping action $\left(Z_{i t-1}\right)$ at time $t-1$ is an indicator of the threat of protection $\left(Z_{i t}^{*}\right)$ at time $t$. In a first step, model (20.19) is estimated as a pooled probit model (a random effects model would be probably a better solution) which allows the authors to compute the predicted probability of protection $\widehat{Z}_{i t-1}$. Finally, this variable is introduced in the Japanese FDI equation:

$$
\mathrm{FDI}_{i t}=\mathbf{x}_{i t} \beta+\widehat{Z}_{i t-1} \delta+\varepsilon_{i t}
$$

\footnotetext{
12 A previous attempt to evaluate quid pro quo FDI was done by Ray (1991). Unfortunatly, the analysis is conducted at industry level, probably inappropriate because trade protection is more often product-specific.
} 
where $\mathbf{x}_{i t}$ contains a variable measuring actual protection in addition to $\widehat{Z}$. Then, this specification evaluates separately actual protection and threat effects. Equation (20.21) can be estimated in a convergent way by OLS if $\eta_{i t-1}$ is independent of $\varepsilon_{i t} .{ }^{13}$ In fact, as FDI values are not systematically reported in their database (ITA), the authors choose to specify their dependent variable in the second equation as the discrete number of FDI occurrences in a 4-digit industry in year $t$. As a result, a random effects negative binomial specification ${ }^{14}$ is adopted which is an extension of the Poisson model by introducing an individual unobserved effect in the conditional mean (each industry is assumed to be characterized by a specific propensity to do FDI). The main result is that Japanese FDI are highly sensitive not only to the actual anti-dumping measures but also to the threat of such measures.

Finally, notice that without the use of panel data (sectors/firms and time), it is probably impossible to split tariff-jumping and qui pro quo effects. Nevertheless, the random effects negative binomial specification requires that $\mathbf{x}_{i t}$ to be strictly exogenous conditional on the unobserved effects. As R\&D expenditures are included in the regressors, this may raise some problems. As suggested by Hausman, Hall and Griliches (1984), it would be useful to estimate a fixed effects negative binomial model which allows for dependence between $\mathbf{x}_{i}$ and the unobserved heterogeneity term.

\subsubsection{Effects of Periods of Trade Liberalization}

Another way to assess the impact of tariffs on FDI is to study how MNFs react during trade liberalization periods or when regional economic integration occurs. Over the past years, there has been an important increase in efforts among countries to achieve regional economic integration. Trade agreements largely differ on the degree of integration they imply: free-trade areas (NAFTA-1994, EFTA-1960); customs unions (Mercosur-1995), common markets (European Single Market-1992); or economic unions (Maastricht Treaty on the European Union-1998). Most studies on the relationship between regional integration and FDI have focused on the EU and NAFTA experiences.

Concerning NAFTA, an interesting analysis is due to Feinberg and Keane (2001). They analyze the effects of US and Canadian tariff reductions on the production location decisions of 701 majority-owned US-based MNF parents and their Canadian affiliates. ${ }^{15}$ Their study has two main interesting features. First, data are observed at a firm level (and not as usually at a more aggregated one industry and/or country level) over a relatively large period (1983-1992) that includes both the Tokyo Round and the Canada-US Free Trade Agreement. Such panel data allow authors to examine the effects of tariff reductions on changes in MNF production-location and, at the same time, to control for time, firm and industry effects. Secondly, the

\footnotetext{
13 See the discussion in Blonigen and Feenstra (1997), and especially footnote 10. See also Maddala (1983).

14 See Hausman, Hall and Griliches (1984).

15 They observe that US and Canadian tariffs dropped by approximately 62.5\% from 1983 to 1992.
} 
authors use a random coefficient approach. ${ }^{16}$ The regression model is expressed as follows:

$$
\begin{aligned}
& r_{i t}=\beta_{0}+\left(\beta_{1}+\mu_{i 1}\right) C T_{i t}+\left(\beta_{2}+\mu_{i 2}\right) U T_{i t} \\
& +\left(\beta_{3}+\tau_{i}\right) \operatorname{TREND}_{t}+\beta_{4} Z_{i t}+\phi_{i}+\varepsilon_{i t} \\
& \text { with } \varepsilon_{i t}=\rho \varepsilon_{i t-1}+\eta_{i t}
\end{aligned}
$$

where $\mu_{i 1} \rightsquigarrow N\left(0, \sigma_{\mu_{1}}^{2}\right), \mu_{i 2} \rightsquigarrow N\left(0, \sigma_{\mu_{2}}^{2}\right)$ and $\tau_{i} \rightsquigarrow N\left(0, \sigma_{\tau}^{2}\right)$. The variable $Y_{i t}$ is defined in different ways, for instance exports from Canadian affiliate $i$ to its US parent or exports from US parent $i$ to its Canadian affiliate. $C T_{i t}$ and $U T_{i t}$ are respectively Canadian and US tariffs in the industry to which firm $i$ belongs at time $t$, and $Z_{i t}$ includes others exogenous variables like transport costs, relative factor costs, GDP for each country and manufacturing wages. Such a specification has several advantages. First, the $\mu_{i}$ 's may capture across-firm heterogeneity in tariff responses whereas $\tau_{i}$ and $\phi_{i}$ control for heterogeneity in the time trend (business cycle) for the former and for unobserved time-invariant firm specific characteristics for the latter. Note also that this specification is quite parsimonious if we compare it to a fixed effects approach. Second, once the population mean for each $\beta$ and the variance of the $\beta_{i}$ s are estimated, the authors construct estimates (a posteriori) of the individual firm $\beta_{i}$. Then they compute the mean of each $\beta_{i}$ within several industries defined at the disaggregated 3-digit level. Lastly, they decompose the total variance of the firm-specific $\beta_{i}$ between across- and within-industries. The main results are twofold. First, the effect of Canadian tariff reductions on US parent exports to Canadian affiliates is very low (a $1 \%$ reduction in the Canadian tariffs increases US parent sales to Canadian affiliates by $1.6 \%$ on average, and moreover, the coefficient is significant only at the $20 \%$ level). At the same time, reductions in the US tariffs imply a greater Canadian affiliate production for sales into the US. Hence, trade liberalization appears to have been trade-creating. .. and does not induce a "hollowing out" of Canadian manufacturing. Second, within-industry (firm) effects explain more than $75 \%$ of the variance in the random tariff coefficient. So, firms' response to a change in the tariff depends heavily on unobserved firm characteristics (technology and organization). Industry characteristics (scale economies and product differentiation) are not a major determinant of the pattern of adjustment even if the industry is narrowly defined. Nevertheless, as noted by the authors themselves, the random coefficients specification may not be adequate if adjustment costs in production are high and if a negative cross-sectional correlation exists, at the preliberalization period, between tariffs and trade flows. ${ }^{17}$ In this case, a fixed-effects Tobit model may be a solution, but its estimation is computationally more difficult.

\footnotetext{
${ }^{16}$ In fact, the model is a random effects tobit model, estimated by ML, because some $Y_{i t}$ are equal to zero, when, for instance, affiliates produce and sell all their production in Canada.

17 See footnote 16, p. 127 in Feinberg and Keane (2001) for more details.
} 
Concerning the EU, there exist many studies on the impact of the various stages of the integration process on FDI. ${ }^{18}$ Typically, regional trading groups, currency unions... are captured by dummy variables. More recent works on this topic rely on two further considerations. First, an integration process takes time to be implemented and absorbed by the economies. So, integration effects must be modeled in a dynamic way, in order to distinguish between short-run and long-run effects and between announcement and post integration effects. Second, as it is necessary to control for many unobserved factors (host and home countries, time, integration phases effects), many dummies have to be introduced in the model, which can lead to a serious loss of degrees of freedom and/or multicollinearity problems. Several recent papers deal with these issues. ${ }^{19}$

Egger and Pfaffermayr (2004-b) try to isolate the impact on FDI of three EU integration phases: the Single Market Program, the 1995 enlargement of the EU and the Agreements between the EU and the Eastern European countries. They use a FDI gravity model with bilateral and time effects in which they add 20 bilateral integration group effects (e.g. EU 12, EFTA, rest of the World, CEEC) interacted with all the three phase dummies (1986-1992, 1993-1994 and 1995-1998) that gives 60 integration dummies. The model, estimated by the within estimator ${ }^{20}$, may be defined as:

$$
\mathrm{FDI}_{i j t}=\mathbf{x}_{i j t} \beta+\alpha+\lambda_{t}+\delta_{i j}+\pi_{k p}+u_{i j t}
$$

where $p(=1,2,3)$ represents the integration phase and $k(=1, \ldots, 20)$ the country group. The estimation period is 1986-1998 and the unbalanced panel contains 3642 observations (with 13 home and 55 host countries). The main conclusion is that the integration effects on FDI are substantial and positive, but largely anticipated by the countries. Once the integration process is officially completed, regional integration has no more effects on FDI. However, the difference-in-differences estimator does not eliminate factors evolving differently over time between countries. So, if unobserved heterogeneity remains in the data, omitted variable bias may be a real problem. Moreover, as the number of countries is not "large" in this work, correct inference may be complicated (see Wooldridge (2003)).

In a very detailed work, Nicoletti, Golub, Hajkova, Mirza and Yoo (2003) use new structural policy indicators constructed by the OECD to estimate the impact of various trade policies on trade and FDI. Among many factors (FDI restrictions, bilateral tariffs and non-tariff protection), they study the role of belonging to a free trade area on FDI. They estimate two bilateral equations of FDI (one for outward stocks, one for outflows). The general model is

\footnotetext{
${ }^{18}$ One of the first attempts is given by Brenton, Di Mauro and Lucke (1999) who unfortunatly do not use the panel dimension of their data.

19 There is a growing empirical literature on this subject, e.g. Girma (2002), Mold (2003), Altomonte and Guagliano (2003), Bevan and Estrin (2004), Carstensen and Toubal (2004) and Yeyati, Stein and Daude (2003) among others. More recent papers take into account the endogeneity of free trade agreements (Baier and Bergstrand (2007)) by of estimating a model on panel data with IV and control-function techniques.

${ }^{20}$ Also called, in this context, the difference-in-differences estimator.
} 


$$
\begin{aligned}
\mathrm{FDI}_{i j t}= & \sum_{x} \beta_{x} \mathbf{X}_{i j t}+\sum_{c} \beta_{c} \mathbf{C}_{i t}+\sum_{p} \beta_{p} \mathbf{P}_{j t} \\
& +\alpha_{i}+\alpha_{j}+\alpha_{i t}+\alpha_{i j}+\alpha_{j t}+u_{i j t}
\end{aligned}
$$

where $i$ (resp., $j$ ) represents the home (resp., host) country, FDI ${ }_{i j t}$ is the log of bilateral FDI outward stocks or flows at time $t, X_{i j t}$ are country-partner pair specific variables, $C_{i t}$ are country specific variables, and $P_{j t}$ are partner pair specific variables. As in Egger and Pfaffermayr (2004-b), the model contains many dummies in order to control for observed and unobserved factors relative to time and (host and home) countries. Nevertheless, Nicoletti et al. adopt a different estimation strategy. Host-specific and home-specific effects are eliminated by using "transformed least squares", i.e., by expressing the data as deviations from the average home country or the average host country. In this way, all home and host specific dummies are removed from the model. They use OECD data described in the previous section, so potentially $28 \times 27 \times 21=15876$ observations are available, but, due to numerous missing values, only about 4500 are used in the estimations. The main conclusion is that participation in free-trade agreements has had significant quantitative effects on FDI, particularly within the EU. For instance, they estimate the increase in FDI stocks to be up to $100 \%$ for Czech Republic, Hungary and Poland between 1990 and 2004.

As shown by the two previous works, dynamic aspects (e.g. anticipations) seem to play a major role when one tries to assert effects of regional integration on FDI.

\subsubsection{Testing the Relationship Between FDI and Exchange Rate}

In the second half of the 1980s the value of the yen increased while the dollar experienced a sharp depreciation. This phenomenon could explain why Japanese FDI increased rapidly in the US during this period. However, the relationship between the exchange rate and FDI is not evident. Under the assumption of a perfect international credit market, firms have the same advantage/disadvantage to purchase any particular asset abroad or at home. In other words, entrepreneurs are able to borrow at the same opportunity cost whatever their location and their nationality. Consequently, the variations of exchange rates do not affect the structure of the private capital account of countries' balance of payments between portfolio investment and FDI. Since the beginning of the 1990s, imperfections in the capital market have become the main argument used in the literature to justify why it is necessary to revisit the relationship between exchange rates and FDI. This question is discussed in the next subsection. We will report empirical studies that highlight the role of imperfections on the product market, on the one hand, and, the volatility of the exchange rate, on the other hand, in the relationship between exchange rate and foreign investments. 


\subsubsection{Role of Imperfections on Capital Markets}

Two types of capital market imperfections play a key role in the relationship between the decision to produce abroad and the exchange rate: the existence of asymmetric information and the capacity of banks to grant loans.

Froot and Stein (1991) propose an adverse selection model where there exists asymmetric information between lenders and borrowers/firms about the future profit from an investment project. Moreover, the creditors incur a monitoring cost if they want to observe the profit realized by the borrowers. This monitoring cost is what causes external resources to be more expensive than internal resources and explains why firms do not finance the whole of their investment by loans. The investment project concerns the purchase of a domestic firm either by another domestic company or by a foreign multinational firm through a bidding process. As the domestic currency experiences a real depreciation, the self-financing capacity of the MNF grows relative to that of the other domestic bidder, so that (ceteris paribus) the MNF increases its probability of winning the auction. From this analysis, the link between real exchange rate and FDI is obvious. ${ }^{21}$

To verify the validity of these different theoretical arguments, Froot and Stein (1991) use annual panel data coming from the International Trade Administration (ITA) of the US Trade Department and for the period 1977-1987. From this database, the authors examine whether the wealth effect may be differentiated across industries or across different types of FDI. Indeed, the US FDI inflows are disaggregated by source country, and by industry as well as by type of purchases/transactions (plant acquisition or expansion, merger and acquisition, joint-ventures). Results suggest that the real exchange rate has not the same effect on the different parts of the total foreign capital inflows into the US. The dollar variations only have a significant effect on inward direct investments, as expected. The estimates of the real exchange rate effects seem more convincing at the level of the different types of FDI transactions. The exchange rate has a statistically significant impact with the right sign on FDI associated with mergers and acquisition operations. ${ }^{22}$

Nevertheless, as the model is estimated by pooled OLS, it does not take into account individual or time effects. This limit is important since no other variables are introduced in the model which control for the alternative explanations of FDI (such as distance, trade costs).

This criticism has been removed by Klein and Rosengren (1994). They adopt the approach retained in Froot and Stein (1991) but consider a fixed-effects specification to take into account the heterogeneity between the source countries. Moreover, considering that the ITA data used by Froot and Stein (1991) are not necessarily comprehensive, Klein and Rosengren prefer to complete their empirical analysis

${ }^{21}$ This analysis does not hold for other types of inward investment such as foreign investment in Treasury securities or in corporate stocks and bonds. For these portfolio investments, the monitoring costs are expected to be small and, thus, uncorrelated with the real exchange rate.

22 The exchange rate has also a significant impact on joint-ventures and new plant FDI. This last result is problematic since the bidding approach developed by authors does not really concern these types of transaction. 
by using the BEA measure of FDI although this includes foreign acquisitions of existing American-target firms and the establishment of new plants by MNF. ${ }^{23}$ The available sample for the BEA series is over the 1979-1991 period while the ITA annual data concern 1977-1987. As in Froot and Stein, the real exchange rate has always a statistically significant impact with the right sign not only on FDI, as a whole, but also on foreign mergers and acquisitions operations. Note that in accordance with the theoretical conclusions of Froot and Stein, the effect is lower on FDI than on mergers and acquisitions. On the other hand, as a log-log specification is only used by Klein and Rosengren, it is difficult to know whether the estimation of the fixed-effects model really modifies the values of the parameters compared to the pooled OLS estimation. In order to control for alternative explanations for FDI, Klein and Rosengren introduce as a regressor in their model the relative-labor-cost between the US and the source countries. They find that the wealth effect is always at work for FDI through mergers and acquisitions in the US while the relative-laborcost has no impact. Then, these different results suggest the empirical validity of the conclusions drawn by Froot and Stein. However, the potential correlation between the disturbances of the models relative to the different type of FDI is not taken into account through, for example, SUR estimation.

However, during the mid-1990s, Japanese FDI fell whereas the yen appreciated significantly. To explain this feature, Klein, Peek and Rosengren (2002) focus on the role played by the financial intermediation. In a country where the relationships between firms and banks are very close, the financial intermediation is dominant. In this context, firms' ability to engage in FDI is influenced by the capacity of banks to grant loans. It is the relative access to credit (RAC) hypothesis. In the 1990s, the Japanese bank sector experienced a collapse causing Japanese firms to be constrained in the financing of their investment projects. Thus, the value of Japanese FDI as a share of total inward US FDI reached a peak of 30\% in 1990 and then declined during the following years by only $1 \%$ of total inward US FDI by 1998. It is the validity of the RAC hypothesis that is tested by Klein, Peek and Rosengren (2002).

A database is constructed by Klein et al. from firm-level FDI ITA over the period 1987-1994. They use the number of FDI projects since the amount of FDI is not systematically available. Moreover, Japanese firm characteristics (size, profitability, market value and industry) come from the Pacific-Basin Capital Markets Databases. From the Japan Company Handbook, are identified the 11 primary (first referenced) banks of the Japanese firms included in the sample. During the sample period, few Japanese firms change their primary bank. In order to obtain an independent/objective evaluation of the banks' financial health and their evolution over the sample period, Klein, Peek and Rosengren (2002) use the time series of Moody's long-term deposit ratings. Thus, the authors exploit the time-heterogeneity between banks although all of them experienced a downgrade in their Moody's ratings during the last years of the period. The empirical model is represented as follows:

\footnotetext{
${ }^{23}$ Despite the difference in definition of FDI, the correlation between the BEA measure and the ITA measure is quite high (0.86). This result confirms the preponderance of mergers and acquisitions in the US inward FDI.
} 


$$
\begin{aligned}
\operatorname{RATEFDI}_{i t}= & \alpha_{0}+\alpha_{1} \text { DPROFIT }_{i t-1}+\text { drating }_{i t-1} \beta \\
& + \text { dmacro }_{i t-1} \gamma+\varepsilon_{i t}
\end{aligned}
$$

where $\varepsilon_{i t} \rightsquigarrow N\left(0, \sigma^{2}\right)$. In this specification, the dependant variable, RATEFDI ${ }_{i t}$, is the variation rate in the number of FDI projects toward the US, financed by Japanese primary bank $i$ during year $t$. drating it-1 $_{\text {c }}$ contains two measures of changes of Moody's long-term deposit ratings for the Japanese main banks. A first dummy variable takes the value 1 if the bank $i$ has a change in its rating, during year $t-1$, and 0 otherwise. Its effect on FDI is a priori negative. A second dummy variable is introduced. Its coefficient is also expected to be negative because this variable takes the value 1 when there are two or more downgrades and 0 otherwise. DPROFIT $i t-1$ corresponds to the variation of the profit sum of the firms associated with bank $i$. This variable measuring the change in the health of firms is assumed to favor FDI. dmacro $_{i t-1}$ contains a set of three macroeconomic variables intended to control for differences in wealth and economic activity between Japan and the US. The first variable is introduced to control the variation of wealth between both countries in the spirit of Froot and Stein (1991). The impact of this variable on FDI should be positive. The change in the US unemployment rate and the change in the Japanese job-offers-to-applicants ratio are used to control for the macroeconomic business cycle in both countries. The effect of these two variables on Japanese FDI to United States is assumed negative.

The coefficients estimated are in accordance with the expectations. Thus, the multiple-level (single-level) downgrade of a bank during the period causes a $70 \%$ $(30 \%)$ reduction in the number of Japanese FDI projects that use this bank as their main lender. On the other hand, the wealth effect is not statistically significant, weakening the argument developed by Froot and Stein (1991). Then, the decreasing number of the Japanese FDI projects in the US over the 1990s seems to be explained by the collapse of the Japanese banking sector rather than by the loss of competitiveness of the Japanese Firms. Moreover, to show the robustness of their estimates, Klein, Peek and Rosengren (2002) provide estimates from two restricted samples including only multiple-year FDI firms or banks financing the most FDI projects. In fact, the individual effects, which are likely to be correlated with some regressors, have not been removed by the variable transformation used. Indeed, the first difference transformation is not applied to the explained variable since DFDI $_{i t}$ is a rate. Therefore, the estimation method is pooled OLS which is biased and inconsistent.

\subsubsection{Role of Imperfection on Product Markets}

The relationship between FDI and the exchange rate can also be explained by imperfections in the product market. Blonigen (1997) establishes three conditions for the existence of a specific relationship between the (real) exchange rate and FDI. First, the opportunity to purchase a target firm which owns a specific asset. The transfer of this specific asset is realized at a low cost between different facilities whatever their nationality. The target firm may be bought either by a (US) domestic firm or by 
a (Japanese) foreign one. Second the domestic and foreign markets are segmented. This market imperfection challenges the law of one price and price adjustments that could compensate for a change in the nominal exchange rate. Third, the access to the foreign market must be limited to the domestic firm. Otherwise, both acquiring rivals would have the same return on the specific asset abroad. Then, the domestic firm knows entry barriers on the foreign market. These three conditions being verified, a real depreciation of the domestic currency (the US dollar) relative to the foreign one (the yen) leads to an increase in the surplus of the foreign firm. Consequently, the foreign firm has an incentive to make a higher bid than its rival for buying the target firm. The direct consequence is that a greater foreign acquisition of the US assets must be expected during a period of real dollar depreciation, other things being equal. This analysis exclusively concerns the inward FDI associated with mergers and acquisitions operations.

From a balanced panel of 361 industries both manufacturing and nonmanufacturing over the period 1975-1992, Blonigen (1997) analyzes the positive relationship between the number of Japanese acquisitions by industry and by year $\left(\mathrm{NFA}_{i t}\right)$ into the US and the real exchange rate $\left(\mathrm{RER}_{i t}\right)$ at industry level. ${ }^{24}$ The specification has the following form:

$$
\operatorname{Pr}\left(\mathrm{NFA}_{i t}\right)=f\left(\mathrm{RER}_{i t}, \Omega_{i t}, \Psi_{i t}\right)
$$

where $\Omega_{i t}$ includes variables having an important role in this approach: (i) the number of acquisitions of US target firms by other US firms (proxying the supply of specific assets on the US market); (ii) the share of Japanese value added in each industry (for the US market penetration of Japanese firm); (iii) the annual real growth of Japanese GDP (a proxy for Japanese demand for specific assets); (iv) the annual growth in the Tokyo Stock Price index (its effect is assumed positive). This variable is used as a proxy for the outgrowth of the speculative "bubble" economy of Japan in the late 1980s and early 1990s. The variables included in $\Psi_{i t}$ must control for other explanations found in the traditional literature on FDI, analyzed previously.

The data on the number of foreign acquisitions are typical of count data which can vary from zero to several or even many, for some industries. The negative binomial model (Hausman, Hall and Griliches (1984)) is used for estimation and represents a generalization of the Poisson distribution with an additional parameter allowing the variance to exceed the mean. Indeed, for the manufacturing and nonmanufacturing sectors over the 1975-1992 period, the number of Japanese acquisitions (NFA) is ranged from 0 to 89 , with a mean of 16 and a standard deviation of 20. Beyond this problem of overdispersion (or underdispersion), the model includes individual fixed or random effects to take into account the cross-sectional heterogeneity. From this model and under the assumption of fixed effects, $\operatorname{Pr}\left(\mathrm{NFA}_{i t}\right)$ can be written as,

$$
\operatorname{Pr}\left(\mathrm{NFA}_{i t}\right)=\frac{\Gamma\left(\lambda_{i t}+\mathrm{NFA}_{i t}\right)}{\Gamma\left(\lambda_{i t} \Gamma\left(\mathrm{NFA}_{i t}+1\right)\right.}\left(\frac{\theta_{i}}{1+\theta_{i}}\right)^{\lambda_{i t}}\left(\frac{1}{1+\theta_{i}}\right)^{\mathrm{NFA}_{i t}}
$$

${ }^{24}$ The dollar value for acquisitions is not retained as a dependent variable since it is missing for over one-third of the observations. 
where $\Gamma$ is the gamma function. The parameter $\theta_{i}$ is the individual effect while $\lambda_{i t}$ depends on the covariates by the following function:

$$
\ln \lambda_{i t}=\alpha \mathrm{RER}_{i t}+\Omega_{i t} \beta+\Psi_{i t} \gamma
$$

Under the assumption that $\mathrm{NFA}_{i t}$ are independent over time, $\Sigma_{t} \mathrm{NFA}_{i t}$ also has a negative binomial distribution with parameters $\theta_{i}$ and $\sum_{t} \lambda_{i t}$. In a context of random effects now, to permit a tractable negative binomial mass function, $\theta_{i} /\left(1+\theta_{i}\right)$ is assumed to be distributed as a beta random variable with shape parameters $(a, b)$. The model with fixed or random effects can be estimated via the maximum-likelihood method Greene (2004).

The estimates of both types of models support the main hypotheses formulated by Blonigen (1997). In other words, a real appreciation of the yen relative to the dollar leads to an increase in the number of Japanese acquisitions in the US. This result holds for manufacturing industries rather than for nonmanufacturing and for the industries with high levels of R\&D. Moreover, the parameters associated with the US supply and Japanese demand of specific assets have the positive expected sign. On the other hand, the alternative explanations of Japanese FDI based on the US tariff-jumping and the Japanese speculative bubble are unsatisfactory. Therefore, these different results exhibit in accordance with Froot and Stein (1991) a wealth effect. However, this effect is mainly present in industries where specific assets like innovation are present and it concerns foreign mergers and acquisitions, the most important component of FDI. Then, this analysis goes further into the specific relationship between FDI and exchange rate..$^{25}$

However, no proxies are introduced to estimate the level of entry barriers in the Japanese markets for the US firms while this is one hypothesis among the most important of this original approach. Moreover, the estimates from random and fixed effects models are both reported but they are not compared using a Hausman test to indicate whether the industry-specific effects are correlated with the regressors. Without results of this specification test, it is difficult to deduce the appropriateness of both models. Another important issue is how to introduce the fixed effects in the negative binomial model. In this case, the fixed effects are conditioned out of the likelihood function (see Allison and Waterman (2002)).

\subsubsection{Role of the Exchange Rate Volatility}

Since the 1970s and the end of generalized system of fixed exchange rates, economists have also devoted much attention to the effects of exchange rate volatility on FDI. The effect of volatility of the real exchange rate on FDI depends on whether firms may choose to export or to invest abroad, on their behavior towards risk and on their expectations about the future profits from FDI.

\footnotetext{
25 These results are broadly supported by the empirical analysis of Guo and Trivedi (2002) that assigns the industries to high- and low-sensitivity FDI categories relative to the exchange rate movements.
} 
Following Dixit (1989), Campa (1993) develops an option model to explain why the MNF make FDI or not (see also Altomonte and Pennings, 2003). In this framework, as opposed to the traditional theory of investments under uncertainty, the expected future profits of a MNF, assumed risk-neutral, take into account the exchange risk of entering the foreign market. ${ }^{26}$ Assuming the future values of the nominal exchange rate are lognormally distributed with a variance $\sigma$ that grows linearly with the time horizon. Then, even if a positive drift may lead to an appreciation of the foreign profits in domestic currency, at the same time the volatility in the future of the nominal exchange rate may be too important to discourage FDI. In fact, the MNF retains an option to enter the foreign market at any moment in time. This option has a price which is the sunk cost of entering the market through FDI. This sunk cost makes an irrevocable commitment of the MNF when it exercises the option. Moreover, the value of the option- equivalent to the value of the investment opportunityis the expected present discounted value of future profits from serving the foreign market minus the amount of FDI realized at time $t$. Here, the decision to make FDI is equivalent to deciding at which time to exercise such an option. The MNF holds back for an extra period (e.g. stays out of the foreign market one more time) as long as the expected change on the option's value is higher than the expected return of the present time. From his theoretical model, Campa (1993) deduces some predictions about the effects of exchange rate volatility on FDI. The higher the exchange rate $R$, the rate of change $\mu$ and the uncertainty $\sigma$, the more valuable the option to enter is and the fewer events of entry observed. Furthermore, the lower the marginal cost MC and the cost to entry in the foreign market $k$, the higher the expectation of future profits from the activity abroad. Note that the marginal cost is not expressed in foreign currency since Campa (1993) limits his empirical analysis to FDI related to wholesale activities. Thus, the model concerns a MNF producing a good in the home country and selling it in a foreign market via a sales subsidiary. The verification of these different predictions allows the author to construct the following reduced form:

$$
n_{i t}^{*}=f\left(\mu, \sigma, e_{f / \$}, k, \mathrm{MC}\right)
$$

where the explained variable, $n_{i t}^{*}$, is the number of MNF that enter the US wholesale trade industry $i$ in a given year $t$. The construction of regressors $\mu$ and $\sigma$ depends on the MNF's expectations about the evolution of these two variables in the future. These two variables correspond to the average and the standard deviation, respectively, of the monthly change in the logarithm of the anticipated exchange rate. Two types of anticipation are considered: perfect and static expectations. The exchange rate level $e_{f / \$}$ is defined as the annual average of the exchange rate in units of domestic currency of the MNF per one unit US dollar, in the year of entry. The level of the sunk costs $k$ is proxied by two variables. The first regressor is the ratio of fixed assets to net wealth of all US firms in an industry and the second is the ratio of media expenditures to turnover in each US industry. The marginal cost MC is proxied

${ }^{26}$ Note that the uncertainty can also concern the foreign production costs (see Brandao De Brito and De Mello Sampayo, 2002) 
by the unit labor cost $w$ since capital is assumed fixed, its cost being included in the entry cost $k$.

The database is a panel of 61 US wholesale trade industries, defined at the fourdigit level, for the period 1981-1987. This sample contains a total of 768 entries of MNF in the US. Even though the MNF come from 35 different countries, the geographical concentration of origin countries is high. Thus, Japan, the UK, Germany, France and Canada account for almost $80 \%$ of the 768 foreign entries on the US markets. The dependant variable $n_{i t}^{*}$ is censored since it takes values from 0 to 40 with a large fraction of zeros. To take account of the truncated distribution of the dependant variable, Campa (1993) uses a Tobit estimation.

The estimates are in accordance with the predictions of the theoretical analysis. Thus, the estimated parameters have the right sign, except for $\mu$. The uncertainty of the exchange rate has a significant negative effect on the number of MNF entering the US markets. The labor cost $w$ is not significant in the estimates weakening the range of the theoretical model. Nevertheless, both proxies of the entry costs Sunk and $A d v$ have significant negative coefficients while the level of the exchange rate $R$ has a positive effect, as expected. However, this last result is the opposite of the conclusions of previous papers where the specific relationship between FDI and the level of exchange rate is explained through market imperfections. In fact, the wealtheffect argument developed by Froot and Stein (1991) is not valid in the present analysis. Indeed, this argument concerns only the FDI realized in manufacturing industries and it cannot be used for FDI in wholesale trade industries.

\subsection{Some Recent Econometric Issues}

The use of panel data presents specific features which introduce econometric complications. In this last section, we discuss two main problems that have been recently treated in the estimation of FDI models.

\subsubsection{FDI, Panel Data and Spatial Econometrics}

The first problem concerns the specification of the empirical model. Recent theoretical developments have stressed that a MNF may engage in FDI activities depending not only on home and host characteristics, but also depending upon the neighboring host's specificities. First, a multinational firm may use a host country as an export platform to other near markets for minimizing trade costs. Second, it may also split its production in several vertical units with respect to the relative factor costs between countries. By definition, an econometric bilateral model of FDI does not take into account the specificities of the neighboring host country. In order to control for the correlation between inward FDI of one country and FDI of its neighbors, we may use spatial panel data model estimation methods. Baltagi, Egger 
and Pfaffermayr (2007) and Blonigen, Davies, Waddell and Naughton (2007) are two interesting studies on this topic. The first one analyzes US outward FDI stock in country-industry pairs (in 1989-1999) whereas the second one focuses on FDI from the US to 20 OECD countries (between 1980-2000). We can summarize their approach as follows (for simplicity, we present mainly the Blonigen et al. methodology, which is simpler - but less general - than Baltagi et al.). Consider that the data are sorted by time $t$ (first sort key) and by host country $j$ (second sort key), so we can omit the $t$ index. For simplicity, we present the specification assuming that the panel is a balanced one $\left(N_{t}=N\right)$,

$$
\mathbf{f d i}=\mathbf{X} \times \beta+\rho \times \mathbf{W} \times \mathbf{f d i}+\mathbf{u}
$$

where fdi and $\mathbf{u}$ are $N \times 1$ vectors (row $j$ refers to the host country $j$ ) and $\mathbf{X}$ is a $N \times k$ matrix of regressors. $\rho \times \mathbf{W} \times \mathbf{f d i}$ reflects the spatial autoregression term, where $\mathbf{W}(N \times N)$ is a (row normalized) spatial lag weighting matrix (for each year $t$ ) (see Chap. 19 in this volume for the expression of $\mathbf{W}$ ) where the components $\left(w\left(d_{i j}\right)\right)$ are a weighted function depending upon the distance between country $i$ and country $j$. According to Blonigen et al., a positive $\rho$ means an agglomeration effect or vertical production organization while a negative $\rho$ suggests FDI are used for export-platform reasons. Further, the spatial error term is defined as

$$
\mathbf{u}=\rho^{\prime} \mathbf{W u}+\varepsilon
$$

with $\left|\rho^{\prime}\right|<1$. Notice also that the Baltagi et al. specification is more general since it includes country-industry-pairs effects and also spatially weighted average of regressors. Errors are spatially correlated when $\rho^{\prime} \neq 0$. However, recall that OLS estimators are still consistent but are inefficient. Finally, one interesting aspect of this model is that $\mathbf{W} \times \mathbf{f d i}$ is endogenous and correlated with $\mathbf{u}$. To estimate this model, Blonigen et al. apply a maximum likelihood method while Baltagi et al. use the fixed and the random effects 2 SLS estimator (using the second and third order spatial lags of the exogenous regressors as instruments).

In Blonigen et al. and Baltagi et al., estimations exhibit a significant spatial dependence, which is negative in the former article and positive in the latter article. In addition, spatial correlation of errors are only detected in Baltagi et al. Even though results are different in some respects, the estimation of a spatial panel data model of FDI is required in order to control for the correlation between the inward FDI of different neighboring countries.

\subsubsection{Exchange Rate, Unit Roots and Cointegration}

As many empirical analysis on FDI very often use non-stationary variables and models in levels, it is necessary to test for unit roots and cointegration in order to avoid spurious regressions. This is a particular problem in FDI-exchange-rate models while it is not treated in the empirical literature (see for example Froot and 
Stein (1991) and Klein, Peek and Rosengren (2002)). Up to now, there have been few studies analyzing FDI determinants on panel data with this methodology which, in the context of countries panel data estimation, presents several specific features.

On the one hand, it is frequently advanced that panel-based unit root tests have higher power than unit root tests based on time series. Indeed, as countries' data are used for FDI analysis, panel data sets are sometimes characterized by large $N$ and large $T$ dimensions. An illustration of such tests is given by Hsiao and Hsiao (2004) who use an (unbalanced) panel data with only 5 countries observed between 1987 and 2002. They apply several tests (for example IPS and ADF-Fisher tests ${ }^{27}$ ) and conclude that FDI is stationary, the exchange rate, GNP and wage differential variables are not. Moreover, they show that the first differences of the non stationary series are $\mathrm{I}(0)$, so these variables are integrated of order one. These results seem to be frequently encountered even if the opposite conclusion is often obtained in the literature about the stationarity of FDI. ${ }^{28}$

On the other hand, given this result, the estimation of FDI determinants, using cross-countries data over time, raises several other issues. First, if the micro relationships are made of I(1) variables where each country has its own specific cointegrating relation, it is probably better to estimate the model on each country separately. Nevertheless, with too few annual periods, making inference in such a context may be difficult. Second, a solution to deal with spurious regressions is to take first differences of the $\mathrm{I}(1)$ variables and to apply usual panel data estimators in a framework of pooling with $\mathrm{I}(0)$ variables. Nonetheless, in this case, variables that are constant in the time dimension are removed from the model and a part of the long-run information is removed. For these reasons, De Santis, Anderton and Hijzen (2004) and Hsiao and Hsiao (2004) suggest proceeding in two steps. First, panel cointegration tests are applied in order to guard against the spurious regression problem. Once again, using panel data may improve the small sample properties of such tests, even if there is not general agreement on this point. From several tests (e.g. multivariate augmented Dickey-Fuller, Im-Pesaran and Shin tests), they reject the null hypothesis that the residuals of the panel regressions are I(1), i.e. they reject the null hypothesis of no cointegration in their panel data. Second, they must decide how to do estimation and inference in panel data cointegration models. ${ }^{29}$ Among many possibilities (e.g. OLS, Mean group, FMOLS, Within estimators), the two studies choose to use the within estimator. Indeed, as the residuals of the within estimator are stationary, within estimates are probably not spurious. ${ }^{30}$ Moreover, when $T$ is large and $N$ is moderately large, Phillips and Moon (1999) shows that the within estimator consistently estimates in many cases the long-run effects and has a limiting normal distribution.

\footnotetext{
${ }^{27}$ See Chap. 9 in this volume.

${ }^{28}$ See Brandão de Brito and Mello Sampayo (2004).

${ }^{29}$ Brandão de Brito and Mello Sampayo (2004) estimate the cointegration relationships and the error-correction mechanism equations for each country separately. As $T=7$, it is not sure that such an approach is correct.

${ }^{30}$ As the De Santis, Anderton and Hijzen (2004) model is a dynamic one, they applied also the Arellano-Bond estimator on first differences and find similar results.
} 
Hsiao and Hsiao (2004) study the determinants of FDI flows in China from Hong Kong, Japan, Taiwan, Korea and the US between 1987 and $2002(N=5$ $\& T=14,15$ or 16 ) whereas De Santis, Anderton and Hijzen (2004) analyze the factors influencing stocks of FDI in the US from eight Euro area countries (1980-2001), so that $N=8$ and $T=22$. Even though the data sets used are different, the specifications are somewhat closed and include some common regressors (lag FDI, exchange rate, GDP and wage differential). Limiting the presentation to the exchange rate, in both studies, a negative and significant relationship is found between the exchange rate and FDI. Nevertheless, as lag FDI is included in the regressors list, it is questionable that the Phillips and Moon (1999) results apply.

Acknowledgments We would like to thank Joe Byrne for helpful comments on an earlier draft.

\section{References}

Allison, P. D. and Waterman, R. (2002). Fixed-Effects Negative Binomial Regression Models. In Stolzenberg R. M. (ed.), Sociological Methodology. Oxford: Basic Blackwell, pp 247-265.

Altomonte, C. and Guagliano, C. (2003). Comparative Study of FDI in Central and Eastern Europe and the Mediterranean. Economic Systems, 27:223-246.

Altomonte, C. and Pennings, E. (2006). The Hazard Rate of Foreign Direct Investment: A Structural Estimation of a Real Option Model. Oxford Bulletin of Economics and Statistics, 68(5):569-593.

Baccheta, M. and Bora, B. (2001). Post-Uruguay Round Market Access Barriers for Industrial Products. Policy Issues in International Trade and Commodities, Study Series No. 12, UNCTAD. New York and Geneva: United Nations.

Baier, S. C. and Bergstrand, H. (2007). Do Free Trade Agreements Actually Increase Members' International Trade? Journal of International Economics, 71(1):72-95.

Balestra, P. and Negassi, S. (1992). A Random Coefficient Simultaneous Equation System with an Application to Foreign Investment by French Firms. Empirical Economics, 17(1):202-220.

Baltagi, B., Egger, P. and Pfaffermayr, M. (2003). A Generalised Design for Bilateral Trade Flow Models. Economics Letters, 80(3):391-397.

Baltagi, B., Egger, P. and Pfaffermayr, M. (2007). Estimating Models of Complex FDI: Are There Third-Country Effects? Journal of Econometrics, 140(1):260-281.

Barell, R. and Pain, N. (1999). Trade Restraints an Japanese Direct Investment Flows. European Economic Review, 43(1):29-45.

Belderbos, R. and Sleuwaegen, L. (1998). Tariff Jumping DFI and Export Subsitution: Japanese Electronics Firms in Europe. International Journal of Industrial Organization, 16(4):601-638.

Bevan, A. and Estrin, S. (2004). The Determinants of Foreign Investment into European Transition Economies. Journal of Comparative Economics, 32:775-787.

Bhagwati, J. N., Dinopoulos, E. and Wong, K.-Y. (1992). Quid Pro Quo Foreign Investment. American Economic Review, 82(2):186-190.

Blonigen, B. A. (1997). Firm-Specific Assets and the Link Between Exchange Rates and Foreign Direct Investment. American Economic Review, 87(3):447-465.

Blonigen, B. A. (2002). Tariff-Jumping Antidumping Duties. Journal of International Economics, 57(1):31-49.

Blonigen, B. A., Davies, R. B. and Head, K. (2003). Estimating the Knowledge-Capital Model of the Multinational Enterprise: Comment. American Economic Review 93:980-994. 
Blonigen, B. A., Davies, R. B., Waddell, G. R. and Naughton, H. (2007). FDI in Space: Spatial Autoregressive Relationships in Foreign Direct Investment. European Economic Review, 51(5):1303-1325.

Blonigen, B. A. and Feenstra, R. C. (1997). Protection Threats and Foreign Direct Investment. In Feenstra, R.C. (ed.), The Effects of U.S. Trade Protection and Promotion Policies. Chicago: National Bureau of Economic Research and University of Chicago Press, pp 55-80.

Blonigen, B. A. and Prusa, T. J. (2003). Antidumping. In Choi, E. K. and Harrigan, J. (eds), Handbook of International Trade. Cambridge, MA: Blackwell Publishers, pp 251-284.

Brainard, S. L. (1997). An Empirical Assessment of the Proximity-Concentration Trade-Off Between Multinational Sales and Trade. American Economic Review, 87(4):520-544.

Brandao De Brito, J. and De Mello Sampayo, F. (2005). The Timing and Probability of FDI: An Application to the United States Multinational Enterprises. Applied Economics, 37(4):417-437.

Brandao de Brito, J. and Mello Sampayo, F. (2004). The Locational Determinants of the U.S. Multinationals Activities. Working Papers, No. 11-04, Banco de Portugal.

Braunerhjelm, P., Ekholm, K., Grundberg, L., and Karpaty, P. (1996). Swedish Multinational Corporations: Recent Trends in Foreign Activities. Research Institute of Industrial Economics (IUI), Working Paper No. 462.

Brenton, P., Di Mauro, F. and Lücke, M. (1999). Economic Integration and FDI: An Empirical Analysis of Foreign Investment in the EU and in Central and Eastern Europe. Empirica, 26(2):95-121.

Campa, J. M. (1993). Entry by Foreign Firms in the United States Under Exchange Rate Uncertainty. Review of Economics and Statistics, 75(4):614-622.

Carr, D. L., Markusen, J. R. and Maskus, K. E. (2001). Estimating the Knowledge-Capital Model of the Multinational Enterprise. American Economic Review, 91(3):693-708.

Carstensen, K. and Toubal, F. (2004). Foreign Direct Investment in Central and Eastern European Countries: A Dynamic Panel Data Analysis. Journal of Comparative Economics, 32:3-22.

Clausing, K. A. (2000). Does Multinational Activity Displace Trade? Economic Inquiry, 38(2):190-205.

De Santis, R. A., Anderton, R. and Hijzen, A. (2004). On the Determinants of Euro Area FDI to the United States: The Knowledge-Capital-Tobin's Q Framework. Working Papers Series, No. 329, European Central Bank.

Dixit, A. (1989). Hysteresis, Import Penetration and Exchange Rate Pass-Through. Quarterly Journal of Economics, 104(2):205-228.

Egger, P. (2001). European Exports and Outward Foreign Direct Investment. Weltwirtschaftliches Archiv, 137(3):427-449.

Egger, P. and Pfaffermayr, M. (2003). The Proper Panel Econometric Specification of the Gravity Equation: A Three-Way Model with Bilateral Interaction. Empirical Economics, 28:571-580.

Egger, P. and Pfaffermayr, M. (2004a). Distance, Trade and FDI: A Hausman-Taylor SUR Approach. Journal of Applied Econometrics, 19(2):227-246.

Egger, P. and Pfaffermayr, M. (2004b). Foreign Direct Investment and European Integration in the 1990s. The World Economy 27(1):99-110.

Falzoni, A. M. (2000). Statistics of Foreign Investment and Multinational Corporations: A Survey. University of Bergamo, Centro de studi Luca d'Agliano and CESPRI.

Feenstra, R. C. (1997). U.S. Exports, 1972-1994: With State Exports and Other U.S. Data. NBER Working Paper 5990. Cambridge, MA: National Bureau of Economic Research, Inc.

Feinberg, S. E. and Keane, M. P. (2001). U.S.-Canada Trade Liberalization and MNC Production. Review of Economics and Statistics, 83(1):118-132.

Feinberg, S. E. and Keane, M. P. (2006). Accounting for the Growth of MNC-Based Trade Using a Structural Model of U.S. MNCs. American Economic Review, 96(5):1515-1558.

Froot, K. A. and Stein J. C. (1991). Exchange Rates and Foreign Diect Investment: An Imperfect Market Approach. Quarterly Journal of Economics, 106(4):1191-1217.

Girma, S. (2002). The Process of European Integration and the Determinants of Entry by Non-EU Multinationals in the UK Manufacturing. The Manchester School, 70:315-335. 
Girma, S., Greenaway, D. and Wakelin, K. (2002). Does Antidumping Stimulate FDI? Evidence from Japanese Firms in the UK. Review of World Economics, 3:414-436.

Greene, W. H. (2004). The Behaviour of the Maximum Likelihood Estimator of Limited Dependent Variable Models in the Presence of Fixed Effects. Econometrics Journal, 7(1):98-119.

Grossman, G. and Helpman, E. (1996). Foreign Investment with Endogenous Protection. In R.C. Feenstra, G.M. Grossman, and D.A. Irwin (eds.), The Political Economy of Trade Policy, Cambridge, MA: MIT Press.

Guo, J. Q. and Trivedi, P. K. (2002). Firm-Specific Assets and the Link between Exchange Rates and Japanese Foreign Direct Investment in the United States: A Re-Examination. Japanese Economic Review, 53(3):337-349.

Hansen, L. P. (1982). Large Sample Properties of Generalized Method Moments Estimators. Econometrica, 50:1029-1054.

Hanson, G. H., Mataloni, R. J. and Slaughter M. J. (2005). Vertical Production Networks in Multinational Firms. Review of Economics and Statistics, 87(4):664-678.

Hausman, J., Hall, B. H. and Griliches, Z. (1984). Econometric Models for Count Data with an Application to the Patents-R\&D Relationship. Econometrica, 52(4):909-938.

Head, K. and Ries J. (2001). Overseas Investment and Firm Exports. Review of International Economics, 9(1):108-122.

Helpman, E. (1984). A Simple Theory of International Trade with Multinational Corporations. Journal of Political Economy, 92(3):451-471.

Helpman, E., Melitz, M. J. and Yeaple, S. R. (2004). Export versus FDI with Heterogeneous Firms. American Economic Review, 94(1):300-316.

Hsiao, F. S. T. and Hsiao, M. C. W. (2004). The Chaotic Attractor of Foreign Direct InvestmentWhy China? A Panel Data Analysis. Journal of Asian Economics, 15(4):641-670.

IMF and OECD (2001). Foreign Direct Investment Statistics: How Countries Measure FDI. Washington, DC: IMF and OECD.

Klein, M. W., Peek, J. and Rosengren E. S. (2002). Troubled Banks, Impaired Foreign Direct Investment: The Role of Relative Access to Credit. American Economic Review, 92(3):664-682.

Klein, M. W. and Rosengren, E. S. (1994). The Real Exchange Rate and Foreign Direct Investment in the United States: Relative Wealth vs. Relative Wage Effects. Journal of International Economics, 36(3-4):373-389.

Lipsey, R. (2001) Foreign Direct Investment and the Operations of Multinational Firms: Concepts, History and Data. NBER Working Paper 8665. Cambridge, MA: National Bareau of Economic Research, Inc.

Maddala, G. S. (1983). Limited-Dependent and Qualitative Variables in Econometrics. Cambridge, MA: Cambridge University Press.

Markusen, J. R. (1984). Multinationals, Multi-Plant Economies, and the Gains from Trade. Journal of International Economics, 16:205-226.

Markusen, J. R. (1995). The Boundaries of Multinational Enterprise and the Theory of International Trade. Journal of Economic Perspectives, 9:169-189.

Markusen, J. R. (1997). Trade versus Investment Liberalization. NBER Working Paper 6231. Cambridge, MA: National Bureau of Economic Research, Inc.

Markusen, J. R. (2002). Multinational Firms and the Theory of International Trade. Cambridge, MA: MIT Press.

Markusen, J. R. and Maskus, K. E. (2002-a). Discriminating Among Alternative Theories of the Multinational Enterprise. Review of International Economics, 10:694-707.

Markusen, J. R. and Maskus, K. E. (2002-b). A Unified Approach to Intra-Industry Trade and Direct Foreign Investment. In Lloyd, P.J. and Lee, H.-H., (eds), Frontiers of Research in IntraIndustry Trade. New York: Palgrave Macmillan, pp 199-219.

Markusen J. R. and Venables, A. (2000). The Theory of Endowment, Intra-Industry and MultiNational Trade. Journal of International Economics, 52:209-234.

Markusen J. R., Venables, A. , Eby-Konan, D. and Zhang, K. (1996). A Unified Treatment of Horizontal Direct Investment, Vertical Direct Investment, and the Pattern of Trade in Goods 
and Services. NBER Working Paper 5696. Cambridge, MA: National Bureau of Economic Research, Inc.

Mátyás, L. (2001). Modelling Export Flows in the APEC Region: Static and Dynamic Gravity Model Approaches. The Asian Pacific Journal of Economics and Business, 5(1):97-118.

Mold, A. (2003). The Impact of the Single Market Programme on the Locational Determinants of US Manufacturing Affiliates: An Econometric Analysis. Journal of Common Market Studies, 41(1):37-62.

Nicoletti, N., Golub, S., Hajkova, D., Mirza, D., and Yoo, K. Y. (2003). Policies and International Integration: Influences on Trade and Foreign Direct Investment, OECD Working Paper No. 359. OECD Economics Department.

OECD (2000). OECD Economic Outlook, 68. Paris

Phillips, P. and Moon, H. (1999). Linear Regression Theory for Non-Stationary Panel Data. Econometrica, 67:1057-1111.

Ray, J. (1991). Foreign Takeovers and New Investments in the United States. Contemporary Policy Issues, 9(2):59-71.

Stephan, M. and Pfaffmann, E. (1998). Detecting the Pitfalls of Data on Foreign Direct Investment: A Guide to the Scope and Limits of FDI-Data as an Indicator of Business Activities of Transnational Corporations. Discussion-Paper 98-02, University of Stuttgart.

Swenson, D. L. (2004). Foreign Investment and the Mediation of Trade Flows. Review of International Economics, 12(4):609-629.

UNCTAD (2002). World Investment Report, Transnational Corporations and Export Competitiveness. United Nations, Geneva.

Wooldridge, J. M. (2003). Cluster-Sample Methods in Applied Econometrics. American Economic Review, 93(2):133-138.

Yeaple, S. R. (2003). The Complex Integration Strategies of Multinationals and Cross Country Dependencies in the Structure of Foreign Direct Investment. Review of Economics and Statistics, 85(3):726-734

Yeyati, A. L., Stein, E. and Daude, C. (2003). Regional Integration and the Location of FDI. Working paper No. 492, Washington, DC: Inter-American Development Bank. 